\title{
KEMAMPUAN EKSTRAK BIJI KELOR SEBAGAI INHIBITOR KOROSI BESI DALAM LARUTAN HCI
}

\author{
Sunarti ${ }^{*}$, Victor Kayadoe ${ }^{1}$, Prima D Rahawarin ${ }^{1}$ \\ ${ }^{1}$ Departement of Chemistry-FKIP, Pattimura University Ambon \\ *sunartihalim835@gmail.com
}

\begin{abstract}
A research to asses the capability of moringa seed in inhibiting corrosion of iron by using weight reduction method has been performed. Inhibition power is obtained based on the inhibition value of varied moringa seed extract concentration variation of $1 \%, 2 \%, 3 \%$, and $4 \%$ as well as temperature variations, namely $35,40,45$, and 50. Resulst showed that, the rate of corrosion inhibition efficiency with varied concentration variation in a row I: $82.92 \% ; 86.87 \% ; 91.02 \% ; 93.74 \%$ and $0.4342 ; 0.3032 ; 0.2235 ; 0.1710$. In the temperature variation data obtained and the rate of corrosion inhibition efficiency in a row: 89,74\%; 88,94\%; 84,94\%; 83,37\% and 0,3986 $\mathrm{mmy}^{-1} ; 0,570 \mathrm{mmy}^{-1} ; 2,1017 \mathrm{mmy}^{-1} ; 9,8384 \mathrm{mmy}^{-1}$.
\end{abstract}

Keyword: moringa seed extracts, iron, inhibitors, inhibition efficiency, methods of weight reduction

\begin{abstract}
ABSTRAK
Telah dilakukan penelitian untuk menguji kemampuan ekstrak biji kelor dalam menghambat korosi besi menggunakan metode pengurangan berat. Daya inhibisi diperoleh berdasarkan nilai efisiensi inhibisi dari variasi konsentrasi ekstrak biji kelor yaitu $1 \%, 2 \%, 3 \%$, dan $4 \%$ serta variasi suhu yaitu $35 \stackrel{\circ}{\circ}$, $40{ }^{\circ} \mathrm{C}, 45 \stackrel{\circ}{\circ}$, dan $50 \stackrel{\circ}{ } \mathrm{C}$. Berdasarkan hasil penelitian diperoleh data efisiensi inhibisi dan laju korosi pada variasi konsentrasi beturut-turut: 82,92\%; 86,87\%; 91,02\%; 93,74\% dan 0,4342 my $^{-1} ; 0,3032$ mmy $^{-1} ; 0,2235$ mmy $^{-1}$; $0,1710 \mathrm{mmy}^{-1}$. Pada variasi suhu diperoleh data efisiensi inhibisi dan laju korosi beturut-turut: $89,74 \% ; 88,94 \%$; $84,94 \% ; 83,37 \%$ dan $0,3986 \mathrm{mmy}^{-1} ; 0,570 \mathrm{mmy}^{-1} ; 2,1017 \mathrm{mmy}^{-1} ; 9,8384 \mathrm{mmy}^{-1}$.
\end{abstract}

Kata Kunci: ekstrak biji kelor, besi, inhibitor, efisiensi inhibisi, metode pengurangan berat.

\section{PENDAHULUAN}

Korosi adalah suatu proses degradasi material atau hilangnya suatu material baik secara kualitas maupun kuantitas akibat adanya proses reaksi kimia dengan lingkungannya (Priyotomo, 2008: 4). Adanya korosi dapat menurunkan kualitas besi sehingga mudah rusak dan patah, sehingga dibutuhkan penanganan khusus untuk mencegah terjadinya korosi. Salah satu upaya menghambat korosi yang dapat dilakukan adalah menggunakan inhibitor korosi.

Umumnya inhibitor korosi berasal dari senyawa-senyawa organik maupun anorganik dengan kandungan gugus-gugus yang memiliki pasangan elektron bebas, seperti nitrit, kromat, fosfat, urea, fenilalanin, imidazolin, dan senyawa-senyawa amina. Namun demikian, pada kenyataannya bahwa bahan kimia sintesis ini umumnya merupakan bahan kimia yang berbahaya terhadap makhluk hidup, harganya relatif mahal, serta tidak ramah lingkungan. Penggunaan senyawa kromat misalnya sudah dilarang digunakan karena bersifat toksik (Firmansyah, 2011: 1). Hal ini mendorong dikembangkannya inhibitor korosi baru terutama yang bersumber dari bahan alam. Penggunaan inhibitor dari bahan alam lebih menguntungkan karena bersifat aman, mudah didapat, ramah lingkungan, dan lebih murah. 
Beberapa penelitian terdahulu telah melaporkan kemampuan bahan alam sebagai inhibitor korosi. Risandi dkk (2012: 31-32) juga melaporkan kemampuan ekstrak daun pepaya (Carica papaya) $1,5 \%$ yang mampu menginhibisi korosi baja St.37 pada media $\mathrm{H}_{2} \mathrm{SO}_{4}$ dan $\mathrm{NaCl}$ masingmasing dengan efisiensi inhibisi sebesar 96,09\% dan 96,22\%. Sari dkk (2013: 211), melaporkan pengendalian laju korosi baja St-37 dalam media asam klorida dan natrium klorida menggunakan inhibitor ekstrak daun teh (Camelia sinens), dengan konsentrasi inhibitor dari 1\%-10\% dan waktu perendaman empat hari, diperoleh nilai efisiensi pada penambahan konsentrasi inhibitor $10 \%$ dalam media $\mathrm{HCl}$ dan $\mathrm{NaCl}$ masing-masing $86,3 \%$ dan $92 \%$.

Khasanah (2008: 11 dan 13), dalam penelitiannya mengatakan bahwa biji kelor mengandung zat aktif 4-alfa-4-rhamnosiloxi-benzil-isothiosianat yang mengandung gugus amin dan gugus tiol yang memiliki pasangan elektron bebas, sehingga dapat mengikat ion-ion logam. Selain itu terdapat asam amino arginin yang mengandung gugus amin, metionin yang memiliki gugus amin dan tiol, dan asam glutamat yang juga mengandung gugus amin dan gugus karboksilat. Ketiganya memiliki gugus fungsi yang mengandung atom-atom penyedia pasangan elektron bebas, sehingga dapat mengikat ion-ion logam. Dengan adanya gugus fungsi tersebut diduga selain dapat digunakan sebagai penjernih air dan koagulan limbah, ekstrak biji kelor juga dapat dijadikan sebagai inhibitor korosi.

Beberapa penelitian yang menggunakan inhibitor dari ekstrak bahan alam telah melaporkan bahwa konsentrasi dan suhu berpengaruh terhadap efisiensi inhibisi dan laju korosi per tahun (Risandi dkk., 2012: 29-30). Dilaporkan bahwa meningkatnya konsentrasi inhibitor mengakibatkan efisiensi inhibisi meningkat, yang berarti bahwa laju korosi menurun. Sementara meningkatnya suhu mengakibatkan efisiensi inhibisi menurun, yang berarti bahwa laju korosi meningkat.

\section{METODE PENELITIAN}

\section{Alat}

Shaker (Carmacell Accoflex 10 x 6 (1/4"D), Evaporator Spektrofotometer IR (Shimadzu), Neraca analitik (ACIS Precision Balance - AD 300), Desikator (Pyrex), Hairdryer (Sayota), Gelas kimia $250 \mathrm{~mL}$ (pyrex), Pompa vakum (WELCH), Corong Buchner, Botol reagen, Labu takar $1000 \mathrm{~mL}$ (pyrex), Spatula, Pipet volume (pyrex), Corong gelas (pyrex), Thermometer $100^{\circ} \mathrm{C}$, Penangas air, Hot plate (CIMAREC), Klem dan statif

\section{Bahan}

Serbuk biji kelor (500 gram), Plat besi $(5,3 \mathrm{~cm} \times 2,3 \mathrm{~cm} \times 0,3 \mathrm{~cm}), \mathrm{HCl}$ pekat $(37 \%), \mathrm{Na}_{2} \mathrm{SO}_{4}$ anhydrous, Aquades, Aseton, Methanol, Kertas saring, Benang, Tissue, Aluminium foil

\section{Prosedur}

\section{Ekstraksi dan variasi konsentrasi inhibitor ekstrak biji kelor}

Pengambilan ekstrak biji kelor dilakukan dengan metode maserasi menggunakan pelarut metanol, perendaman dilakukan selama 3x24 jam. Dilanjutkan dengan evaporasi untuk menguapkan pelarut. Kemudian ekstrak biji kelor $100 \%$ divariasikan konsentrasinya menjadi $1 \%, 2 \%, 3 \%, 4 \%$ dengan cara menambahkan inhibitor langsung ke dalam media korosi (\%v/v).

\section{Pengukuran inhibisi dengan metode pengurangan berat}

Spesimen besi ditimbang dengan neraca analitik kemudian direndam pada media korosi tanpa inhibitor dan dengan inhibitor (variasi konsentrasi inhibitor 1\%, 2\%, 3\%, 4\%) selama 4 hari pada suhu ruang. Setelah diangkat, dibilas dengan aquades dan dikeringkan. Spesimen besi 
ditimbang dengan neraca analitik untuk mengetahui pengurangan beratnya. Kemudian dihitung $\%$ efisiensi inhibisinya dan laju korosi per tahun.

\section{Pengukuran pengaruh suhu}

Spesimen besi yang sudah bersih dan kering ditimbang dengan neraca analitik kemudian direndam pada media korosi yang memiliki efisiensi inhibisi tertinggi dengan variasi suhu $35^{\circ} \mathrm{C}$, $40^{\circ} \mathrm{C}, 45^{\circ} \mathrm{C}$, dan $50^{\circ} \mathrm{C}$ dan didiamkan selama 4 jam di dalam penangas air dengan tetap menjaga suhu yang diinginkan. Setelah 4 jam, hot plate dimatikan dan besi diangkat kemudian dicuci dan dikeringkan lalu ditimbang. Pengaruh suhu dapat diketahui dengan menghitung laju korosi besi per tahun dalam media $\mathrm{HCl}$ dengan variasi suhu di atas.

Kemampuan inhibisi korosi dari ekstrak biji dapat diketahui dengan menghitung laju korosi per tahun dan efisiensi inhibisi. Laju korosi pertahun dapat dihitung dengan metode kehilangan berat atau weight gain loss (WGL):

$$
R=\frac{K \cdot \Delta W}{A \cdot t \cdot D}
$$

Dimana, $R\left(\mathrm{mmy}^{-1}\right)=$ Laju korosi $\left(\mathrm{mm} /\right.$ year), $\mathrm{D}=$ Densitas $\left(\right.$ besi $\left.7,9 \mathrm{~g} / \mathrm{cm}^{3}\right), \Delta \mathrm{W}=$ Berat yang hilang (gram), $t=$ Waktu (jam), $A=$ Luas permukaan $\left(\mathrm{cm}^{2}\right), K=$ Konstanta $\left(8,76 \times 10^{4}\right.$ jam/tahun. $\mathrm{mm} / \mathrm{cm})$.

Efisiensi insibisi digunakan dihitung dengan menggunakan rumus,

$\%$ Efisiensi Inhibisi $(E I)=\frac{W o-W i}{W o} X 100$

Dimana, Wo = berat logam yang hilang sebelum ditambahkan inhibitor, $\mathrm{Wi}=$ berat logam yang hilang setelah ditambahkan inhibitor

\section{HASIL PENELITIAN}

\section{A. Identifikasi Gugus Fungsi Ekstrak Metanol Biji Kelor}

Sebelum diaplikasikan dalam media korosi, terlebih dahulu biji kelor diekstarksi. Ekstraksi dilakukan dengan cara maserasi menggunakan pelarut organik yang bersifat polar yaitu metanol agar dapat mengekstrak senyawa dalam biji kelor yang terlarut baik dalam pelarut polar.

Ekstrak yang diperoleh kemudian dianalisis dengan FTIR untuk mengetahui adanya gugusgugus fungsi yang terkandung dalam ekstrak. Spektra FTIR ekstrak biji kelor ditunjukkan pada Gambar 1. 


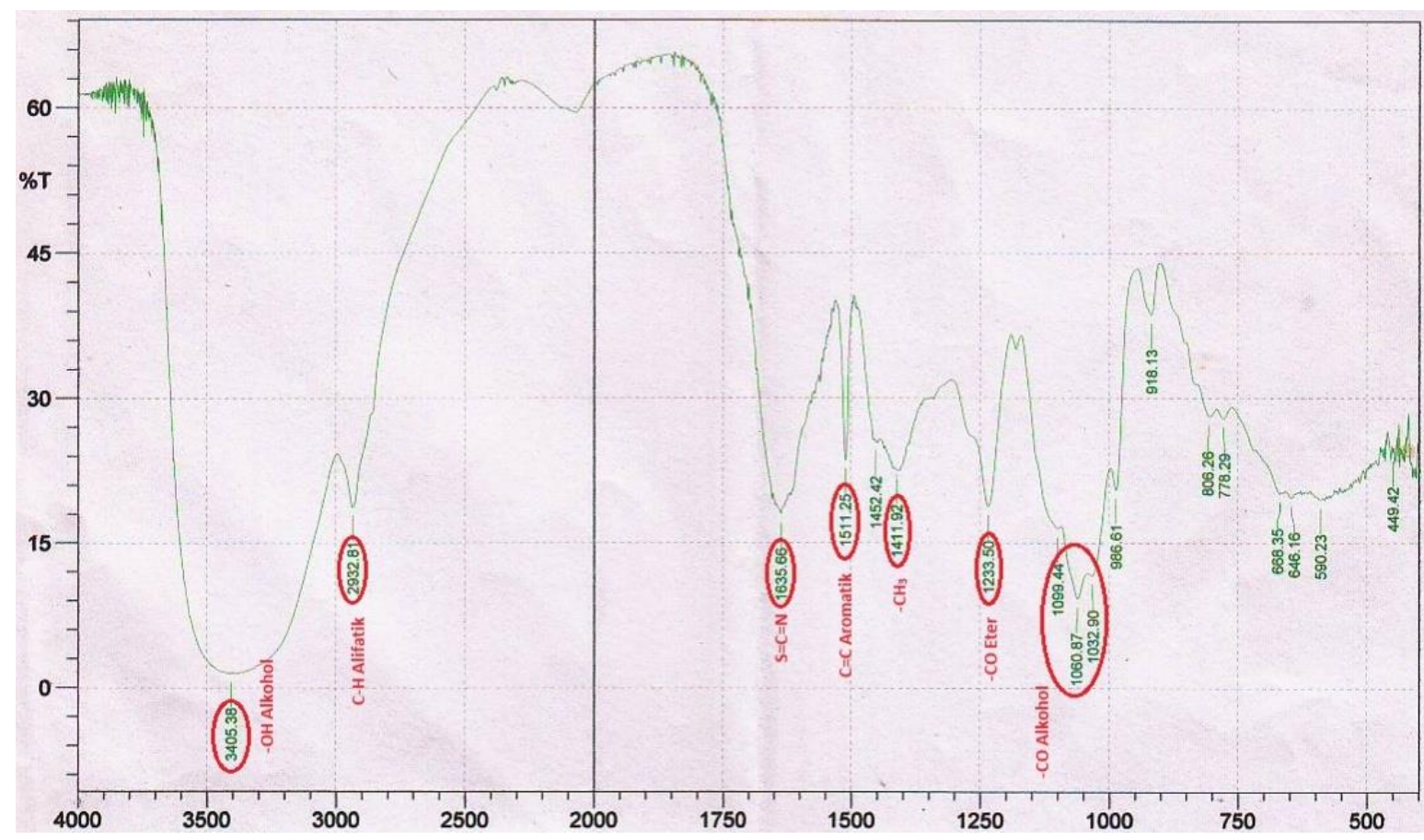

Gambar 1. Spektra FTIR ekstrak biji kelor

Berdasarkan Gambar 1 terlihat ada beberapa gugus fungsi yang terkandung dalam ekstrak biji kelor. Adanya pita lebar dan kuat pada bilangan gelombang $3405,38 \mathrm{~cm}^{-1}$ yang merupakan gugus $\mathrm{O}-\mathrm{H}$ diperkuat dengan serapan $\mathrm{C}-\mathrm{O}$ eter pada bilangan gelombang $1233,50 \mathrm{~cm}^{-1}$; SCN pada bilangan gelombang $1635,66 \mathrm{~cm}^{-1}$; serapan $\mathrm{C}=\mathrm{C}$ aromatik pada bilangan gelombang $1511,25 \mathrm{~cm}^{-1}$ yang diperkuat dengan dua serapan pada daerah $806,26 \mathrm{~cm}^{-1}$ yang menjadi ciri khas adanya senyawa aromatik; $\mathrm{CH}$ terkonjugasi dari aromatik ditunjukkan pada bilangan gelombang 2931,81 $\mathrm{cm}^{-1}$; serapan pada bilangan gelombang $1411,92 \mathrm{~cm}^{-1}$ yang menunjukkan adanya $\mathrm{CH}$ alifatik. Dari hasil analisis FTIR senyawa yang terekstrak dari biji kelor mengandung senyawa 4a-4-ramnosiloxi benzil isotiosianat, hal ini didasarkan pada munculnya gugus $\mathrm{S}=\mathrm{C}=\mathrm{N}$ dan beberapa gugus-gugus yang terdapat dalam struktur $4 \alpha-4$-ramnosiloxi benzil isotiosianat pada spektrum IR (Dulanlebit dkk, 2020).<smiles>CC1OC2Oc3ccc(CN=C=S)cc3OC(C2O)C(O)C1O</smiles>

Gambar 2. Struktur 4a-4-rhamnosyloxi benzil isotiosianat 


\section{B. Efisiensi Inhibisi dan Laju Korosi Berdasarkan Konsentrasi Ekstrak Biji Kelor}

Keberadaan ion $\mathrm{H}^{+}$dalam media korosi $(\mathrm{HCl})$ mengakibatkan zat tersebut bersifat agresif terhadap pelarutan logam. Pengamatan saat uji korosi menunjukkan gas $\mathrm{H}_{2}$ yang dihasilkan saat perendaman besi dalam media $\mathrm{HCl}$ tanpa inhibitor lebih banyak dibandingkan dalam media $\mathrm{HCl}$ dengan penambahan inhibitor, hal ini ditunjukkan oleh banyaknya gelembung yang terbentuk selama proses perendaman. Reaksi sel yang berlangsung selama perendaman logam besi dalam media $\mathrm{HCl}$ adalah sebagai berikut:

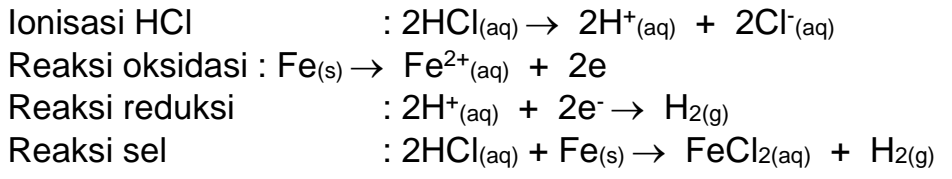

Hasil pengujian variasi konsentrasi ekstrak biji kelor terhadap efisiensi inhibisi dan laju korosi per tahun besi dalam media $\mathrm{HCl} 1 \mathrm{M}$ ditunjukkan pada Tabel 1.

Tabel 1. Efisiensi Inhibisi (\%) dan Laju Korosi Per Tahun $\left(\mathrm{mmy}^{-1}\right)$ berdasarkan variasi Konsentrasi Ekstrak Biji Kelor terhadap Besi dalam Media $\mathrm{HCl}$

\begin{tabular}{ccccccc}
\hline $\begin{array}{c}\text { Konsentrasi } \\
\text { Ekstrak Biji } \\
\text { Kelor }(\%)\end{array}$ & $\begin{array}{c}\text { Luas } \\
\text { Permukaaan } \\
\text { Besi }\left(\mathrm{cm}^{2}\right)\end{array}$ & $\begin{array}{c}\text { Berat } \\
\text { Awal } \\
(\mathrm{g})\end{array}$ & $\begin{array}{c}\text { Berat } \\
\text { Akhir } \\
(\mathrm{g})\end{array}$ & $\begin{array}{c}\text { Selisih } \\
\text { Berat } \\
(\mathrm{g})\end{array}$ & El (\%) & $\begin{array}{c}\text { Laju Korosi } \\
\text { Per tahun } \\
\left(\mathrm{mmy}^{-1}\right)\end{array}$ \\
\hline 0 & 29,50 & 28,4891 & 27,8766 & 0,6125 & - & 2,3982 \\
1 & 27,82 & 27,0180 & 26,9134 & 0,1046 & $82,92 \%$ & 0,4342 \\
2 & 30,62 & 29,2857 & 29,2053 & 0,0804 & $86,87 \%$ & 0,3032 \\
3 & 28,42 & 27,2816 & 27,2366 & 0,0550 & $91,02 \%$ & 0,2235 \\
4 & 25,87 & 26,4827 & 26,4444 & 0,0383 & $93,74 \%$ & 0,1710 \\
\hline
\end{tabular}

Berdasarkan Tabel 1, Pengurangan berat besi semakin rendah dengan meningkatnya konsentrasi ekstrak biji kelor yang ditambahkan ke dalam media korosi. Hal ini karena semakin banyak lapisan pasif pada permukaan logam yang dibentuk oleh inhibitor sehingga memperkecil bagian aktif logam besi. Sesuai dengan yang dilaporkan oleh Firmansyah (2011: 39) bahwa nilai efisiensi inhibisi semakin meningkat dengan penambahan konsentrasi ekstrak daun sirsak menunjukkan bahwa dengan penambahan komponen inhibitor yang teradsorpsi dipermukaan logam akan menghalangi atau menutup bagian aktif yang seharusnya terkorosi oleh $\mathrm{HCl}$. Kondisi ini mengakibatkan semakin berkurangnya berat besi yang terlarut dalam media korosi.

Efisiensi inhibisi akan semakin meningkat dengan bertambahnya konsentrasi, hingga mencapai $93,74 \%$ pada konsentrasi $4 \%$. Peningkatan efisiensi inhibisi ini mengakibatkan menurunnya laju korosi per tahun $\left(\mathrm{mmy}^{-1}\right)$ dari 2,3982 $\mathrm{mmy}^{-1}$ menjadi 0,1710 $\mathrm{mmy}^{-1}$, yang berarti bahwa besi dapat digunakan dalam jangka waktu lebih lama jika diberikan inhibitor ekstrak biji kelor 4\%. Data Hubungan antara efisiensi inhibisi dan laju korosi terhadap konsentrasi ekstrak biji kelor pada penelitian ini, ditunjukkan pada Gambar 3 


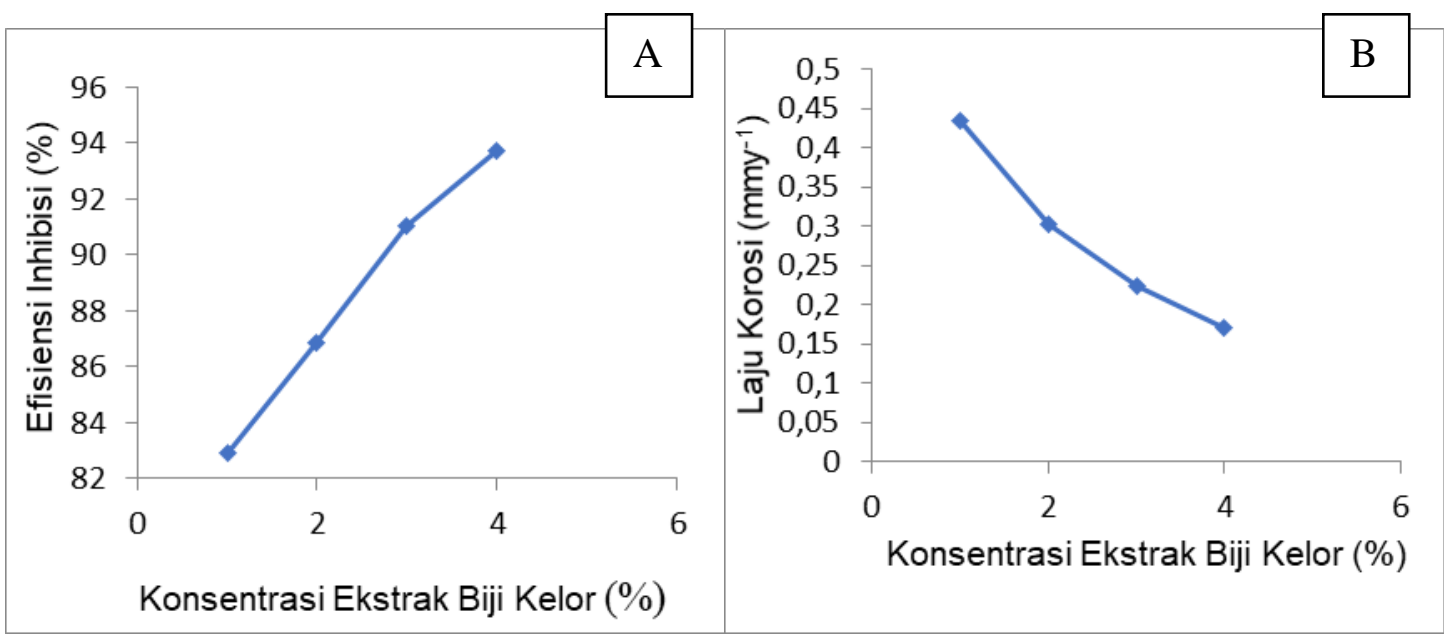

Gambar 3. Grafik hubungan \%El terhadap konsentrasi ekstrak biji kelor (A) dan laju korosi terhadap konsentrasi ekstrak biji kelor $(B)$ dalam media $\mathrm{HCl}$

Daya inhibis korosi dari ekstark biji kelor berasal dari gugus isotiosianat dimana atom $\mathrm{S}$ dan atom $\mathrm{N}$ mendonorkan pasangan elektronnya pada permukaan besi sehingga membentuk ikatan koordinasi. Setiap orbital kosong yang dimiliki oleh $\mathrm{Fe}^{2+}$ di isi oleh elektron bebas yang dimiliki atom $S$ dari senyawa 4a-4-rhamnosyloxy benzil isotiosianat. Keberadaan orbital $4 p$ dan 4d karena ligan yang dimiliki oleh zat aktif merupakan ligan lemah yang tidak dapat masuk ke orbital $3 d$, sehingga diperlukan orbital bayangan untuk membentuk senyawa kompleks dengan inhibitor. Haryono dkk (2010: 3) mengatakan bahwa atom yang memiliki pasangan elektron bebas akan mendonorkan pasangan elektronnya kepada $\mathrm{Fe}^{2+}$ sehingga mencegah agar ion $\mathrm{Fe}^{2+}$ tidak terdifusi ke dalam larutan elektrolit. Bukan hanya atom $\mathrm{S}$ yang dapat mendonorkan pasangan elektronnya, setiap atom-atom yang memiliki pasangan elektron dalam senyawa $4 \alpha-4$-ramnosyloxy benzil isotiosianat juga dapat mendonorkan pasangan elektronnya untuk membentuk senyawa kompleks dengan $\mathrm{Fe}^{2+}$ (Rani and Basu, 2012: 2).

\section{Efisiensi dan Laju Korosi Besi dalam Media HCI Berdasarkan Suhu}

Hasil uji korosi dengan variasi konsentrasi ekstrak biji kelor didapatkan nilai \% efisiensi inhibisi tertinggi pada media $\mathrm{HCl}$ dengan penambahan ekstrak biji kelor $4 \%$. Konsentrasi media korosi dengan ekstrak biji kelor yang menghasilkan nilai \% efisiensi inhibisi tertinggi ini selanjutnya digunakan untuk mempelajari pengaruh suhu terhadap \% efisiensi inhibisi dan laju korosi $\left(\mathrm{mmy}^{-1}\right)$ besi dalam larutan $\mathrm{HCl}$, dengan variabel lain yang sama yaitu waktu perendaman 4 jam dan konsentrasi $\mathrm{HCl}$ 0,96 $\mathrm{M}$ untuk media korosi uji maupun kontrol. Hasil pengujiannya ditunjukkan pada Tabel .2

Tabel 2. Pengaruh Suhu terhadap Efisiensi Inhibisi (\%) Korosi Besi dalam Media $\mathrm{HCl}$

\begin{tabular}{cccccccc}
\hline $\begin{array}{c}\text { Suhu } \\
\left({ }^{\circ} \mathrm{C}\right)\end{array}$ & \multicolumn{3}{c}{ Berat Besi } & \multicolumn{3}{c}{ Berat Besi } & El \\
& \multicolumn{2}{c}{ Tanpa Inhibitor (Wo) } & \multicolumn{3}{c}{ dengan Inhibitor (Wi) } & $(\%)$ \\
& Awal & Akhir & $\Delta$ Wo & Awal & Akhir & $\Delta$ Wi & \\
& $(\mathrm{g})$ & $(\mathrm{g})$ & $(\mathrm{g})$ & $(\mathrm{g})$ & $(\mathrm{g})$ & $(\mathrm{g})$ & \\
\hline 35 & 26,9174 & 26,8745 & 0,0429 & 30,1682 & 30,1638 & 0,0044 & 89,74 \\
\hline
\end{tabular}




\begin{tabular}{llllllll}
\hline 40 & 27,0209 & 26,9639 & 0,0570 & 30,1582 & 30,1519 & 0,0063 & 88,94 \\
45 & 27,1903 & 27,0362 & 0,1541 & 30,1259 & 30,1027 & 0,0232 & 84,94 \\
50 & 26,8306 & 26,2773 & 0,6533 & 30,0855 & 29,9769 & 0,1086 & 83,37 \\
\hline
\end{tabular}

Tabel 2 memperlihatkan bahwa pada suhu yang sama, pengurangan berat besi tanpa inhibitor lebih besar dibandingkan dengan pengurangan berat besi dengan adanya inhibitor. Pada suhu $35^{\circ} \mathrm{C}$, pengurangan berat besi akibat korosi tanpa inhibitor $(\Delta \mathrm{Wo})$, yakni $0,0429 \mathrm{gram}$ lebih besar dibandingkan pengurangan berat besi dengan inhibitor $(\Delta \mathrm{Wi})$, yakni 0,0044 gram demikian juga pada suhu yang lainnya. Hal ini menunjukkan adanya peranan inhibitor ekstrak biji kelor dalam menghambat proses korosi besi dalam media $\mathrm{HCl}$ pada semua suhu sistem yang divariasikan.

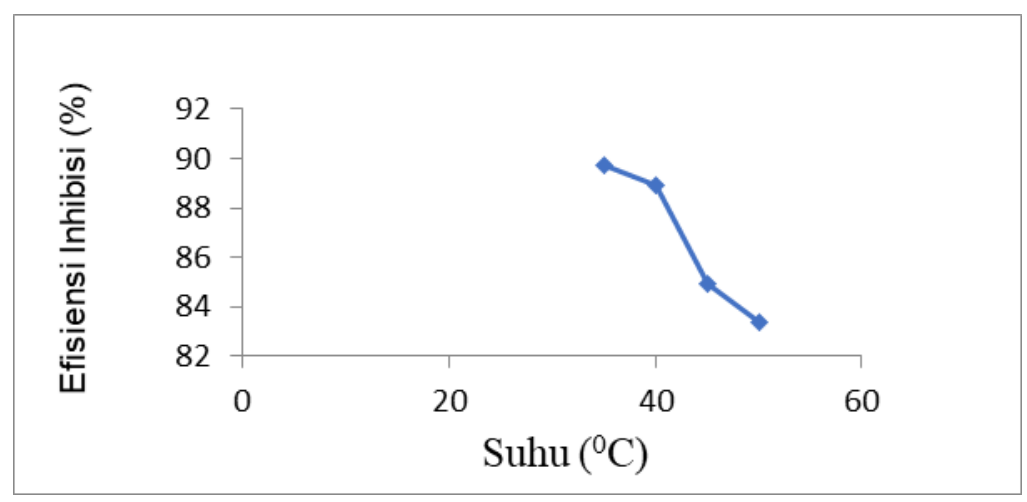

Gambar 4. Grafik Hubungan \%El terhadap suhu

Gambar 4. mengindikasikan bahwa inhibitor ekstrak biji kelor pada suhu yang relatif tinggi mengalami penurunan daya inhibisi terhadap serangan korosi. Hal ini sejalan dengan penelitian Jalajaa dkk (2019) bahwa semakin tinggi suhu maka kemampuan inhibisi korosi ektrak kulit kayu pohon kelor dalam medium asam klorida semakin menurun. Proses terjadinya korosi ini dipengaruhi oleh suhu elektrolit. Hal ini disebabkan dengan meningkatnya temperatur maka meningkat pula energi kinetik partikel sehingga kemungkinan terjadinya tumbukan efektif pada reaksi redoks semakin besar. Dengan demikian laju korosi pada logam semakin meningkat (Misbah dan Nova, 2012: 13). Selain itu proses korosi pada suhu tinggi juga dipengaruhi oleh adanya kompetisi difusi molekul inhibitor dengan zat korosif pada permukaan logam, besarnya ukuran molekul senyawa inhibitor mengakibatkan difusinya lambat sehingga pada suhu tinggi, permukaan logam akan lebih dahulu diserang zat korosif yang memiliki ukuran molekul lebih kecil sehingga pergerakannya lebih cepat.

Khaleel, et al (2018) menyatakan bahwa perubahan suhu mempunyai pengaruh yang sangat besar terhadap proses aktivasi laju difusi reaktan. Dengan adanya suhu tinggi, ionisasi larutan asam akan semakin cepat dan pori-pori permukaan logam akan semakin besar. Kondisi ini mengakibatkan difusi zat asam dan molekul oksigen pada permukaan logam akan semakin cepat, sehingga pelarutan logam akan semakin cepat. Pengaruh suhu terhadap laju korosi per tahun $\left(\mathrm{mmy}^{-1}\right)$ besi dalam media $\mathrm{HCl}$ dengan dan tanpa inhibitor ekstrak biji kelor ditunjukkan pada Tabel 3. 
Tabel 3. Pengaruh suhu terhadap laju korosi per tahun $\left(\mathrm{mmy}^{-1}\right)$ besi dalam media $\mathrm{HCl}$ dengan dan tanpa ekstrak biji kelor

\begin{tabular}{ccccccc}
\hline $\begin{array}{c}\text { Suhu } \\
\left({ }^{\circ} \mathrm{C}\right)\end{array}$ & \multicolumn{2}{c}{$\begin{array}{c}\text { Luas Permukaan } \\
\text { Besi }\left(\mathrm{cm}^{2}\right)\end{array}$} & \multicolumn{2}{c}{$\begin{array}{c}\text { Selisih Berat Besi } \\
(\mathrm{g})\end{array}$} & \multicolumn{2}{c}{$\begin{array}{c}\text { Laju Korosi Per Tahun } \\
\left(\mathrm{mmy}^{-1}\right)\end{array}$} \\
& $\begin{array}{c}\text { Tanpa } \\
\text { Inhbitor }\end{array}$ & $\begin{array}{c}\text { Dengan } \\
\text { Inhibitor }\end{array}$ & $\begin{array}{c}\text { Tanpa } \\
\text { Inhbitor }\end{array}$ & $\begin{array}{c}\text { Dengan } \\
\text { Inhibitor }\end{array}$ & Tanpa Inhibitor & $\begin{array}{c}\text { Dengan } \\
\text { Inhibitor }\end{array}$ \\
\hline 35 & 25,36 & 30,6 & 0,0429 & 0,0044 & 4,6894 & 0,3986 \\
40 & 25,36 & 30,6 & 0,0570 & 0,0063 & 6,2963 & 0,5707 \\
45 & 25,36 & 30,6 & 0,1541 & 0,0232 & 16,8449 & 2,1017 \\
50 & 25,36 & 30,6 & 0,6533 & 0,1086 & 71,4135 & 9,8384 \\
\hline
\end{tabular}

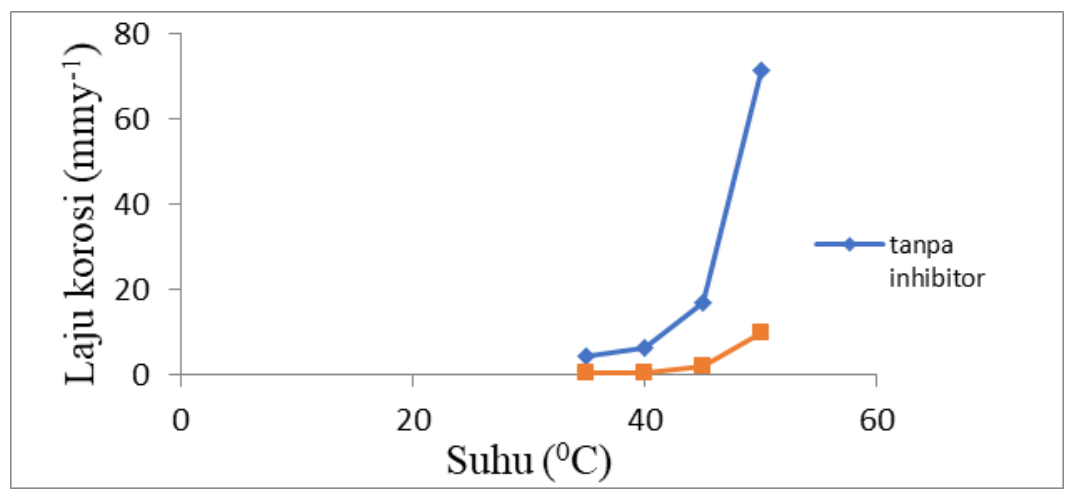

Berdasarkan Tabel 3 dan gambar 5 nilai laju korosi tanpa inhibitor lebih tinggi dibandingkan dengan inhibitor yang berarti inhibitor ekstrak biji kelor masih dapat menghambat laju korosi besi pada semua variasi suhu yang digunakan meskipun tidak sebaik pada suhu ruang. Dari data tersebut maka dapat disimpulkan bahwa besi akan mengalami korosi lebih cepat jika pada penggunaannya diaplikasikan untuk proses yang menggunakan suhu tinggi.

\section{KESIMPULAN}

Berdasarkan hasil penelitian diperoleh data efisiensi inhibisi dan laju korosi pada variasi konsentrasi beturut-turut: 82,92\%; 86,87\%; 91,02\%; 93,74\% dan 0,4342 $\mathrm{mmy}^{-1} ; 0,3032 \mathrm{mmy}^{-1}$; $0,2235 \mathrm{mmy}^{-1} ; 0,1710 \mathrm{mmy}^{-1}$. Data ini menunjukkan bahwa semakin tinggi konsentrasi ekstrak biji kelor yang ditambahkan maka semakin rendah laju korosi pertahun. Pada perlakuan suhu diperoleh data efisiensi inhibisi dan laju korosi beturut-turut: 89,74\%; 88,94\%; 84,94\%; 83,37\% dan $0,3986 \mathrm{mmy}^{-1} ; 0,570 \mathrm{mmy}^{-1} ; 2,1017 \mathrm{mmy}^{-1} ; 9,8384 \mathrm{mmy}^{-1}$. Data ini menunjukkan bahwa peningkatan suhu akan meningkatkan laju korosi walaupun dengan penambahan inhibitor 


\section{DAFTAR PUSTAKA}

D Jalajaa, S. Jyothi, V.R. Muruganantham, and J. Mallika (2019) Moringa Oleivera Gum Exudate As Corossion Inhibitor on Mild Steel In Acid Medium, Rasayan.J.Chem Vol.12, No. 2, ISSN: 0974-1496 / e- ISSN: 0976-0083 (545-548)

Firmansyah, D. (2011). Studi Inhibisi Korosi Baja Karbon dalam Larutan Asam 1M HCL oleh Ekstrak Daun Sirsak (Annona Muricata), Tesis. Depok: Fakultas Teknik, Universitas Indonesia

Haryono, G., Sugiarto, B., Farid, H., dan Tanoto, Y. (2010). Ekstrak Bahan Alam sebagai Inhibitor Korosi. Prosiding Seminar Nasional Teknik Kimia "Kejuangan". ISSN: 1693-4393: Yoyakarta

Hawraa khaleel, Adnan A, Ateeq, Amjed A, Ali, (2018), The Effect of Temperature and Inhibitor on Corrositon of Carbon Steel in Acid Solution under Static Study, International Journal of Applied Enginering Research ISSN 0973-4562 Volume 13, Number 6, 3638-3647

Misbah, M. N., dan Nova, S. M. K. (2012). Analisis Pengaruh Salinitas dan Suhu Air Laut Terhadap Laju Korosi Baja A36 Pada Pengelasan SMAW. Jurnal Teknik ITS. ,ISSN: 2301-9271. Vol. 1(1)

Priyotomo, G. (2008). Kamus Saku Korosi Material, Free E-Book Edisi Mahasiswa. 1.1

Risandi, Y., Emriadi., dan Stiadi, Y. (2012). Ekstrak Daun Pepaya (Carica papaya) Sebagai Inhibitor Korosi Baja St.37 dalam Medium Asam Sulfat. Jurnal Kimia Unand. Vol. 1(1): 27-33

Sari, D. M., Handani, S., dan Yetri, Y. (2013). Pengendalian Laju Korosi Baja St-37 Dalam Medium Asam Klorida dan Natrium Klorida Menggunakan Inhibitor Ekstrak Daun Teh (Camelia sinensis). Jurnal Fisika Unand. ISSN: 2302-8491. Vol. 2(3): 204-211

Yeanchon H. Dulanlebit, Sunarti, Yustinus T. Male (2020), Efektifitas Biji Kelor ( Moringa oleifera. Lamk) Pada Pengolahan Air Sumur dan Penentuan Waktu Optimum Adsorpsi Biji Kelor Terhadap Fe dan Mg dalam Air, MjoCe. Vol. 10. No.1 (43-52) 